\title{
ARCHITECTURE AND STRATIGRAPHIC FRAMEWORK OF SHELF SEDIMENTARY SYSTEMS OFF RIO DE JANEIRO STATE, NORTHERN SANTOS BASIN-BRAZIL*,
}

\author{
Renata Moreira da Costa Maia ${ }^{l}$; Antonio Tadeu dos Reis $^{2+}$; Eliane da Costa Alves ${ }^{l}$; Cleverson Guizan Silva ${ }^{l}$; \\ Josefa Varela Guerra ${ }^{2}$; Christian Gorini ${ }^{3}$; Adalberto Silva ${ }^{1}$ and Rodrigo Arantes-Oliveira ${ }^{2}$ \\ ${ }^{1}$ Universidade Federal Fluminense - UFF \\ Departamento de Geologia, LAGEMAR \\ (Av. General Milton Tavares de Souza, s/n, 4 andar, 24210-346 Niterói, RJ, Brasil) \\ ${ }^{2}$ Universidade do Estado do Rio de Janeiro - UERJ \\ Departamento de Oceanografia Geológica - Faculdade de Oceanografia \\ (Rua São Francisco Xavier, 524, $4^{\circ}$ andar, 20550-900 Rio de Janeiro, RJ, Brasil) \\ ${ }^{3}$ Université Pierre et Marie Curie-Paris 6, France \\ Lab. Evolution et Modélisation des Bassins Sédimentaires, Institut des Sciences de la Terre Paris (iSTeP) - \\ CNRS UMR 7193, \\ (4 place Jussieu - case 117, Tour 56-66, 5ème étage, 75252 Paris cedex 05, France) \\ ${ }^{+}$Corresponding author: antonio.tadeu@pq.cnpq.br
}

\begin{abstract}
A B S T R A C T
Seismic analysis of sparker lines of GEOMAR cruises allowed us to address a first stratigraphic scenario for the shallow sedimentary record $(\sim 300 \mathrm{msec})$ of the continental shelf off Rio de Janeiro State, northern Santos basin. Two sets of seismic sequences were identified and interpreted as a succession of depositional sequences induced by repeated glacioeustatic cycles. Depositional sequences composing Set I (SqA-SqC) are dominantly sigmoidal, reflecting periods of increasing accommodation space that favoured the preservation of both aggradational and progradational units; sequences of Set II (Sq1-Sq5) are essentially seaward-thickening stacks of forced-regression wedges, implying periods of declining accommodation space. Comparison between seismic lines and chronostratigraphic data allowed the mapped sequences to be placed within the Plio-Quaternary. Correlations also suggest that most of Set I (SqA and lower portion of $\mathrm{SqB}$ ) was deposited during the Pliocene (undifferentiated Pliocene), while the upper portion of sequence SqC and sequences of Set II (Sq1-Sq5) have been placed within the Quaternary. Correlation of chronostratigraphic data with $\delta^{18} \mathrm{O}$ isotopic "sea level curves" also supports the hypothesis that sequences Sq1-Sq4 are fourth-order forced-regression sequences that record 100-120 kyr glacioeustatic cycles for the last 440-500 kyr, while sedimentary units labeled Sq5 would represent the transgressive and highstand deposition during the Holocene.
\end{abstract}

\section{R E S U M O}

A análise sísmica de dados sparker das Operações GEOMAR permitiu a elaboração de um primeiro arcabouço estratigráfico da seção rasa $(\sim 300 \mathrm{msec})$ da plataforma continental do Estado do Rio de Janeiro, norte da bacia de Santos. Dois conjuntos de sequiências sísmicas foram interpretados como sequiências deposicionais induzidas por oscilações glacio-eustáticas. O Conjunto I ( $\mathrm{SqA}-\mathrm{SqC})$, composto por seqüências dominantemente sigmoidais, reflete condições de geração de espaço de acomodação sedimentar capaz de preservar seus componentes agradacionais-progradacionais; o Conjunto II (Sq1-Sq5), composto principalmente por prismas de regressão forçada, indica diminuição relativa de espaço de acomodação. Dados cronoestratigráficos de poços permitiram posicionar a seção sísmica investigada na janela plio-quaternária: à maior parte do Conjunto $\mathrm{I}(\mathrm{SqA}$ e parte inferior da $\mathrm{SqB})$ foi atribuída uma idade Plioceno (indiferenciado); à seção estratigráfica que se estende da porção superior da $\mathrm{SqC}$ até o Conjunto II foi atribuída uma idade quaternária. A correlação entre a base de dados e curvas globais de variações isotópicas de $\delta^{18} \mathrm{O}$ permitiu ainda sugerir que as sequiências Sq1-Sq4 registram sequências regressivas de quarta ordem (ciclos glacio-eustáticos de cerca de 100-120 ka) durante os últimos 440-500 ka. A sequência Sq5 representaria a deposição holocênica, constituída por depósitos transgressivos e de sistemas de mar alto.

Descriptors: Continental shelf, Forced regression, Quaternary, Pliocene, Glacioeustatic oscillations, Eastern Brazilian Margin.

Descritores: Plataforma continental, Regressão forçada, Quaternário, Plioceno, Oscilações glacioeustáticas, Margem continental leste brasileira.

(*) This is a contribution of the research group GEOMARGEM-Geology and Oceanography of Passive Continental Margins (http://www.geomargem.org).

(**) Paper presented at the INTERNATIONAL GEOLOGICAL CORRELATION PROGRAM PROJECT NO. 526 - RISKS, RESOURCES, AND RECORD OF THE PAST ON THE CONTINENTAL SHELF: MINING LATE QUATERNARY GEOLOGICAL EVIDENCE, 2., 2008, Natal, UFRN. 


\section{INTRODUCTION}

Studies from different geological settings around the world provide examples of sedimentary architecture of Plio-Quaternary continental shelf systems related to the interplay among several factors such as the amplitude and frequency of glacioeustatic oscillations, variable rates of sediment supply and prevailing tectonic regime (e. g. FOYLE; OERTEL, 1997; TRINCARDI; CORREGGIARI, 2000 TESSON et al., 2000; HERNANDEZ-MOLINA et al., 2000; RIDENTE; TRINCARDI, 2002; JIN et al., 2002; LOFI et al., 2003; RABINEAU et al., 2005; GROSSMAN et al., 2006; TEZCAN; OKYAR, 2006; LIQUETE et al., 2008; TRIPSANAS; PIPER, 2008). During the Plio-Quaternary, high-frequency and highamplitude sea-level oscillations stand as one of the major elements inducing base level variations that control the morphological and stratigraphic evolution of prograding continental shelves. Concerning the middle-late Pleistocene, high-amplitude glacioeustatic signals $( \pm 100-120 \mathrm{~m})$ are characterized by slow sealevel falls and rapid sea-level rises, punctuated by short-lived intervals of sea-level highstand and stillstand conditions (SHACKLETON; OPDYKE, 1976; CHAPPEL; SHACKLETON, 1986; CLARK et al. 2006). Sea-level oscillations are, therefore, intense and dominated by the falling part of the glacioeustatic cycles (RABINEAU et al., 2006), which favours the deposition of forced-regression deposits (POSAMENTIER et al., 1992; POSAMENTIER MORRIS, 2000). Forced-regression conditions reflect the process of seaward migration of the shoreline in direct response to falling relative sea-level, regardless of the rate of sediment supply (POSAMENTIER et al., 1992; HUNT; TUCKER, 1992; POSAMENTIER; MORRIS, 2000; PLINT; NUMMEDAL, 2000).

The occurrence of high rates of clastic influx into the Santos basin is known to have forced massive shelf progradation during the late Cretaceous and notably during the Paleogene (MOREIRA; CARMINATTI, 2004; MODICA; BRUSH, 2004). These depositional conditions prevailed until the Oligocene, when the Paraíba do Sul River, that discharged into the northern Santos basin, was captured and reorganized to its present-day coastparallel orientation and diverted into the Campos basin (Fig. 1) (MODICA; BRUSH, 2004). As a consequence, the shelf environment was drowned and became relatively starved of clastic input; at the same time, the shelf edge backstepped more than $50 \mathrm{~km}$ landward from the Late Eocene shelf edge, close to its present-day position (Fig. 1).

However, very few studies have dealt with the stratigraphic and physiographic evolution of the Santos basin shelf sedimentary section during the Pliocene or the Quaternary. Most of the studies dealing with the Quaternary section have focused on the shelf morphology, superficial or subsurface sediment distribution or on the geomorphology and stratigraphic evolution of coastal features, like bays, coastal plains and the shallow shelf environments during the Holocene (e.g. KOWSMANN; COSTA, 1979; MAIA et al., 1984; MUEHE, 1989; MUEHE; CARVALHO, 1993; MUEHE; VALENTINI, 1998; TURCQ et al, 1999; MARTIN et al., 2003; ARTUSI; FIGUEIREDO, 2007; MAHIQUES et al., 2007; FLEMING et al., 2009). Therefore, the PlioQuaternary stratigraphic window remains as an important gap in the attempt to reconstruct the sedimentary history of the Santos basin continental shelf and of the Brazilian continental margin, as a whole.

In this paper we investigate and discuss, based on seismic and exploratory well data, the stratigraphic architecture of continental shelf systems off Rio de Janeiro State, in order to address a first stratigraphic framework of the shallow section of the northern Santos basin.

\section{Material and Methods}

The stratigraphic analysis carried out in this study was based primarily on the interpretation of about $5,000 \mathrm{~km}$ of single-channel sparker seismic lines (500-1000 Joules, 100 to $1400 \mathrm{~Hz}$ ), acquired on the continental shelf of the Santos and Campos basins during legs XVI and XX of GEOMAR Oceanographic Cruises $^{1}$ in the early 80's (Fig. 1). Maximum signal penetration ranges from 300 to $400 \mathrm{msec}$, while the vertical resolution oscillates between circa 7 and $12 \mathrm{~m}$, depending on the seismic line considered. Additionally, exploratory well information (wells P1 and P2) was provided by the Brazilian National Petroleum Agency - ANP, while regional bathymetric data were extracted from ETOPO2 (SMITH; SANDWELL, 1997) (Fig. 1).

Interpretation of seismic data was implemented according to the general principles of high resolution seismic and sequence stratigraphy, more adequate to address analyses of Quaternary high frequency glacioeustatic signals (fourth and fifthorders, circa 100-120, 40 and $20 \mathrm{kyr}$ depositional cycles, e.g. TESSON et al., 1990; HUNT; TUCKER, 1992; POSAMENTIER et al., 1992; EVANS et al., 1995; PLINT; NUMMEDAL, 2000; POSAMENTIER; MORRIS, 2000; CATUNEANU, 2002; CATUNEANU, 2006; CATUNEANU et al.,

\footnotetext{
${ }^{1}$ A total of 24 legs of GEOMAR oceanographic cruises were carried out between 1969 and 1986 in a joint scientific programme between Brazilian universities and governmental agencies, aiming at the acquisition of seismic data, sub-bottom profiling and sediment sampling throughout the Brazilian continental margin.
} 
2009). To calculate the thickness of each seismic sequence, an estimated layer velocity of $1600 \mathrm{~m} / \mathrm{s}$ was considered.

In the study area, no ages of paleoshorelines nor of measured or estimated sea-level curves from cores are available, either for the LGM (Last Glacial Maximum) or for earlier cycles and glacial maxima. For this reason, for a first approximation of high-frequency and amplitudes of Quaternary sea-level variations, we used a compilation of global sea-level curves based on $\delta^{18} \mathrm{O}$ isotopic ratio calibrated by the dating of geological evidence, such as morphologic, diagenetic or organic features, on continental margins (RABINEAU et al., 2006).

\section{Results}

The study area comprises the east-west oriented continental shelf about $400 \mathrm{~km}$ long and between 70 and $120 \mathrm{~km}$ wide, off Rio de Janeiro State, northern Santos basin. It extends from Cabo Frio, on the east, to São Sebastião island, on the west, presenting a rather gentle seaward-dipping gradient of about $0.07^{\circ}$ (Fig. 2). The shelf break is irregular, displaying large indentations between Cabo Frio and São Sebastião (Figs 1 and 2). The continental shelf is about $70 \mathrm{~km}$ wide and $170 \mathrm{~m}$ deep offshore of the Araruama lagoon (Figs 2 and 3); whereas it is wider $(\sim 120 \mathrm{~km})$ and deeper $(\sim 200 \mathrm{~m})$ off Sepetiba-São Sebastião on its western limits (Figs 2 and 4).

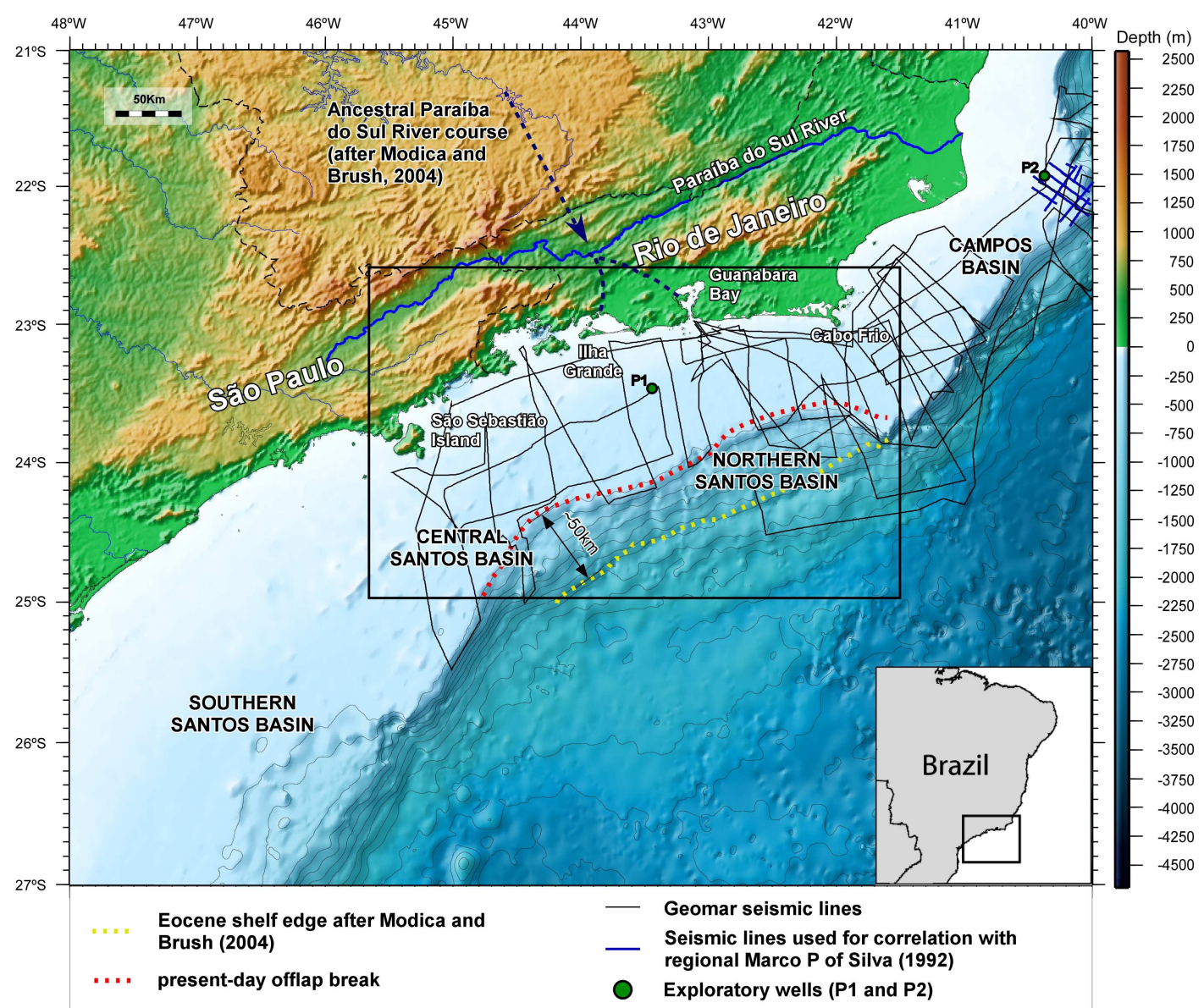

Fig. 1. Regional bathymetric map of the Santos basin with location of the study area and of the tracklines of the single-channel seismic data and exploratory wells used in this work. Regional bathymetry data are from ETOPO2 (SMITH; SANDWELL, 1997). 
Seismic stratigraphic analysis shows a pattern of stacked seismic units that together constitute eight major seismic sequences bounded by angular unconformities. Mapped seismic sequences reveal depositional features of a mostly prograding shelf, defined by the continuous seaward displacement of successive offlap breaks of outer shelf sedimentary wedges (Figs 3 and 4). In accordance with the geometry of their clinoforms and internal architecture, the seismic sequences were grouped into two distinctive stratigraphic sets, identified as Sets I and II. Surface S1 distinguishes these two stratigraphic sets of sequences as a high amplitude reflector that portrays an erosive surface easily mappable on the shallow seismic lines and thus representing a key horizon to distinguish Set I from Set II (COSTA MAIA, 2009) (Fig. 3)

Sequences that compose the lower stratigraphic set (Set I shown in shades of gray and numbered $\mathrm{SqA}-\mathrm{SqC}$ bottom-up in figure 3 ) are easily identifiable on the eastern sector of the shelf, but are relatively poorly-imaged on the western sector, either due to multiple reflections or because of weak acoustic return (Fig. 4). Nevertheless, seismic data show that in the inner-mid shelf, sequences $\mathrm{SqA}, \mathrm{SqB}$ and $\mathrm{SqC}$ are composed of plan-parallel seismic units (after MITCHUM et al., 1977; seismic facies $P P$ in figure 5). In contrast, in the outer shelf, these sequences are composed of seismic units consisting of sigmoidal clinoforms (after MITCHUM et al., 1977; seismic facies $S C$ in figure 5). On the eastern sector of the shelf, seismic units $\mathrm{SqA}$ to $\mathrm{SqC}$ can grade seaward into parallel-oblique clinoforms (after MITCHUM et al., 1977), composing prograding sedimentary wedges of relatively high angle of dipping foresets $\left(\sim 0.9-1.0^{\circ}\right)$ (Fig. 3 and seismic facies $O C$ in figure 5a). These seismic units form individual prograding sedimentary wedges that can reach a maximum thickness of up to $35-45 \mathrm{msec}$ (i.e., $\sim 25-35 \mathrm{~m}$ ) on the mid-shelf and about $80-100 \mathrm{msec}$ (i.e., $\sim 65-80 \mathrm{~m}$ ) at the level of their respective offlap breaks (Fig. 3).

Seismic sequences Sq1-Sq4, that compose the upper stratigraphic set (Set II, numbered Sq1-Sq5 bottom-up in Figs 3 and 4), are laterally correlatable at the regional scale of the study area between Cabo Frio and São Sebastião island (Fig. 2). These seismic sequences differ broadly from sequences that make up Set I: sequences $\mathrm{Sq} 1, \mathrm{Sq} 2$ and $\mathrm{Sq} 3$ are composed of seaward-thickening parallel-oblique clinoforms (after MITCHUM et al., 1977), are bounded above and below by internal truncation surfaces of local extent, and present toplap terminations of about $0.2-0.3^{\circ}$ (Fig. 4 and seismic facies $O C$ in Fig. 5). These seismic units form individual prograding sedimentary wedges that can reach a maximum thickness of up to $100-130 \mathrm{msec}$ (i.e., $80-105 \mathrm{~m}$ ) at the level of their respective offlap breaks (Figs 3 and 4). Distinct geometries and internal reflection patterns are exhibited by seismic sequences $\mathrm{Sq} 4$ and Sq5. Seismic data from several sectors of the study area evidence that on the inner shelf $\mathrm{Sq} 4$ consists mainly of plan-parallel tabular seismic units $(\sim 25-30 \mathrm{~m}$ thick) that grade into parallel-oblique clinoforms located farther seaward at the distal end of the shelf (Figs 3 and 4). On the other hand, the architectural style and overall thickness and distribution of the youngest top seismic sequence Sq5 are quite variable across the shelf and contrast markedly with the depositional styles of sequences Sq1-Sq4 (Figs 3 and 4). Sequence Sq5 is unevenly distributed throughout the study area: on the mid-outer shelf, it is represented either by local dune-like features (not exceeding circa $18 \mathrm{~m}$ thick, Figs 2 and $6 b$ ), or by a patchy sedimentary cover (up to about 15 $30 \mathrm{~m}$ thick, Figs 2 and 6c, d) infilling erosive depressions carved on surface S5. On the inner shelf, Sq5 consists of a continuous along-strike wedge-like sedimentary prism, up to $15 \mathrm{~m}$ thick, that roughly follows the $50 \mathrm{~m}$ isobath from east to west (Figs 2 and $6 a)$.

Seismic sequences are bounded by subhorizontal or gently-inclined seaward-dipping reflectors, expressed by irregular surfaces identified as SA, SB and S1 to S5 (Figs 3 and 4). On the inner-mid shelf, the top of each sequence of Set I (surfaces SA, $\mathrm{SB}$ and S1) is usually a smooth erosive surface that grades seaward into enhanced erosional surfaces characterized by toplap terminations (Fig. 5A). In contrast, the top of each sequence of Set II (reflectors $\mathrm{S} 2$ to S5) is an erosive and frequently stepped-topped surface that truncates the underlying seismic sequences $\mathrm{Sq} 1$ to $\mathrm{Sq} 4$ in a toplap termination (examples in Fig. 5). Erosive surfaces S2, S3 and S4, though topping underlying sequences of limited updip extent, merge landward with the underlying surface $\mathrm{S} 1$ to become shelf-wide erosive surfaces (Figs 3 and 4).

As a general pattern, seismic sequences that compose Set I (SqA-SqC) stack on top of each other as composite shelf-wide sigmoidal and paralleloblique prograding clinoforms, resulting in shelf wedges that prograded for about $25 \mathrm{~km}$ (Fig. 3). Contrastly, the seismic sequences that compose Set II (Sq1-Sq5) show highly variable thicknesses in the depositional dip. Seismic sequences Sq1-Sq3 stack on top of each other and have a more limited extent. They consistently pinch out in a progressively landward direction showing significant thickness variation over short distances on the outer shelf (Figs 2, 3 and 4). Sequence $\mathrm{Sq} 4$, on the other hand, is a laterally continuous shelf-wide sequence, constituted mainly of plan-parallel seismic units for most of its landward extent, though some contribution of the progradational component is observed at the shelf break (Figs 3 and 4). As a consequence, seismic sequences Sq1-Sq4 form a composite seaward-thickening shelf wedge, 
whose front prograded seawards for about $15-25 \mathrm{~km}$ in the study area (Figs 3 and 4). These sequences can reach a maximum thickness of about $180-220 \mathrm{~m}$ at the level of the present-day offlap break, forming clinofoms that dip at higher angles than those of Set I (examples in Figs 3 and 4).

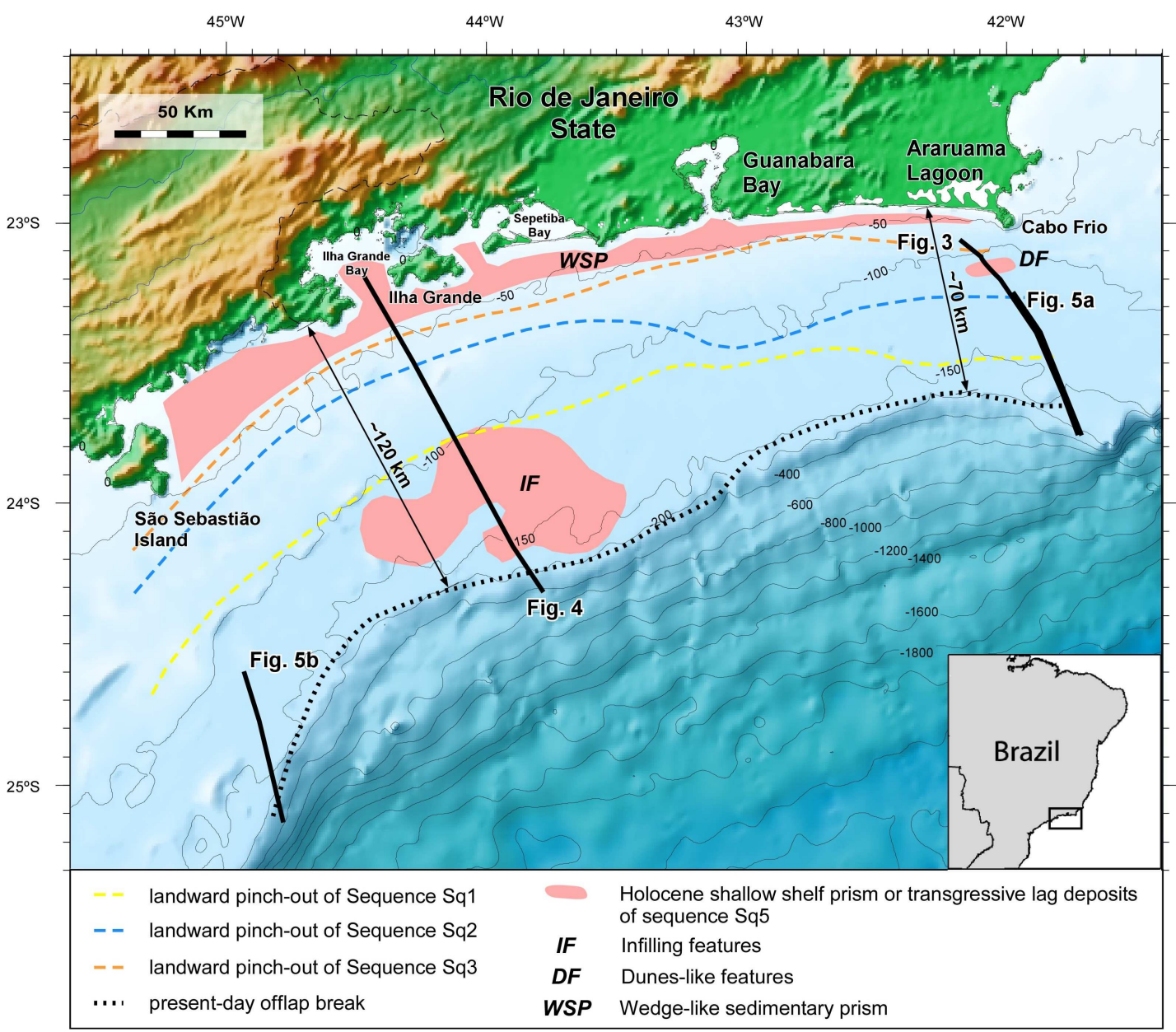

Fig. 2. Bathymetric map of the continental shelf off Rio de Janeiro State, northern Santos basin, illustrating features and stratigraphic elements concerning the shallow sedimentary record $(\sim 300 \mathrm{msec})$. 


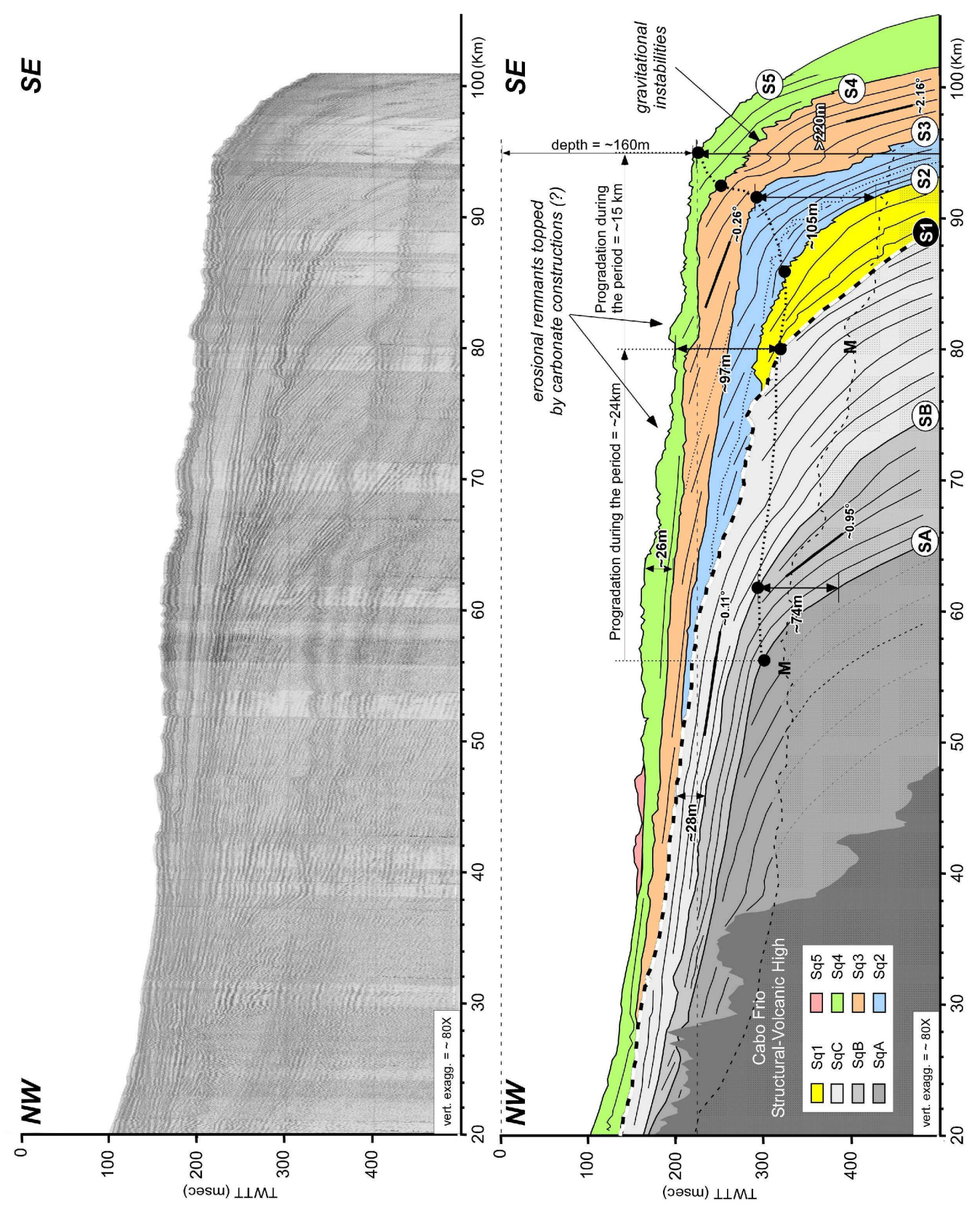

Fig. 3. Top-Uninterpreted dip single-channel seismic line across the eastern shelf sector off Rio de Janeiro (close do Cabo Frio). Bottom- Linedrawing illustrating a lower set of aggradational-progradational sigmoidal clinoforms (SqA-SqC) topped by a stacking of five seismic sequences (Sq1-Sq5), composed of shelf-edge clinoform wedges (Sq1-Sq4) and dune-like features (Sq5). Dotted line $=$ offlap break trajectory of the prograding continental shelf. See Figure 2 for location. 


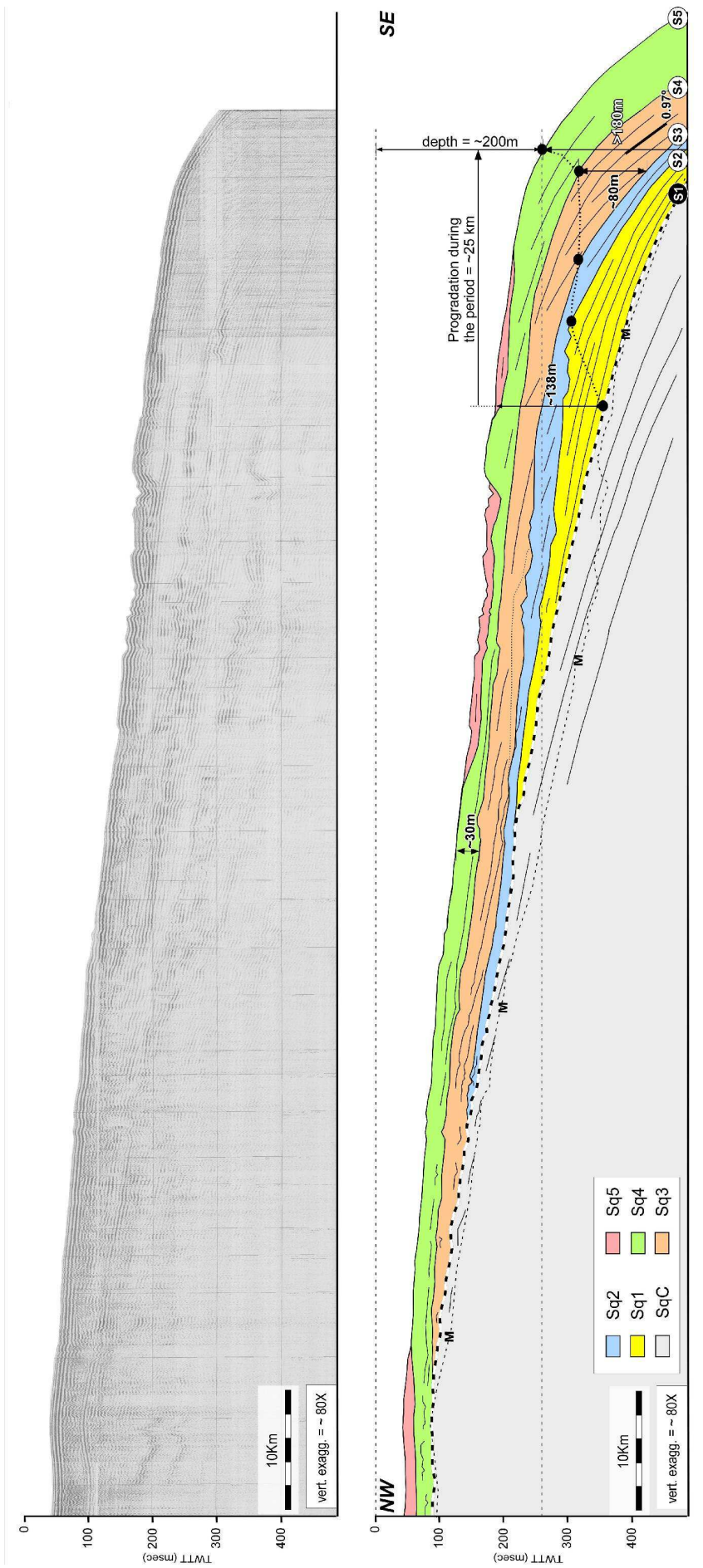

Fig. 4. Top-Uninterpreted dip single-channel seismic across the western shelf sector off Rio de Janeiro (offshore Ilha Grande Bay). Bottom- Linedrawing illustrating a stacking of five seismic sequences (Sq1-Sq5), composed of shelf-edge clinoform wedges (Sq1-Sq4) and localized infilling sedimentary units (Sq5) on the outer shelf. Dotted line $=$ offlap break trajectory of the prograding continental shelf. See Figure 2 for location. 

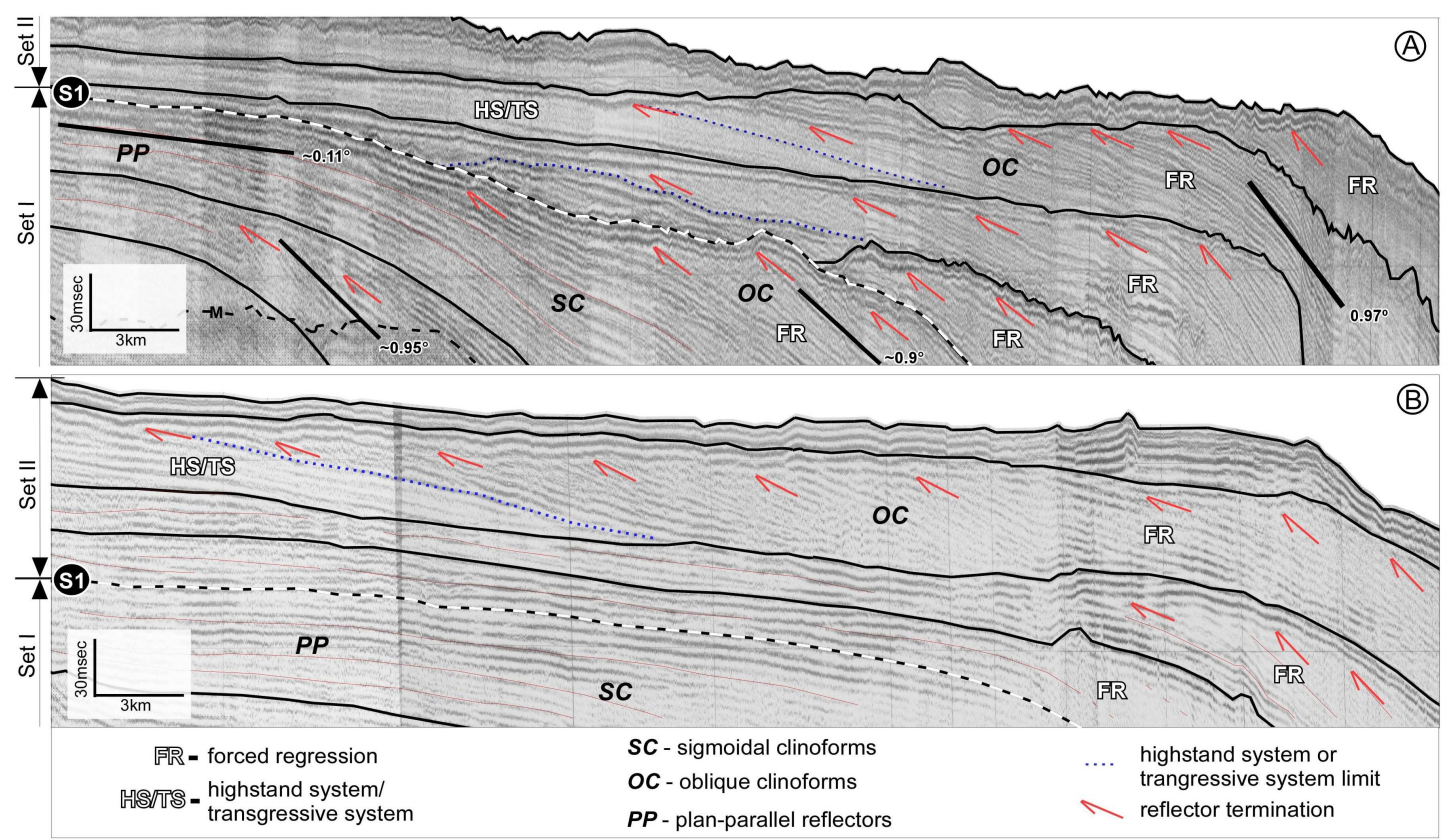

Fig. 5. Zoom-in of dip single-channel seismic lines across the outer shelf off Rio de Janeiro State. A and B illustrate distinct geometrical relationships displayed by seismic reflections, as well as various reflection patterns and external geometries that characterise the prograding continental shelf systems in the study area. See Figure 2 for location.

\section{Discussion}

Seismic stratigraphic analysis of GEOMAR XVI and XX data sets carried out in this study made it possible to subdivide the upper stratigraphic section of the northern Santos basin into definable depositional packages bounded by laterally continuous surfaces.

Seismic sequences of Set I (SqA-SqC, Figs 3 and 4) and Set II (Sq1-Sq5, Figs 3 and 4) are bounded by rather irregular bottom and top surfaces, suggesting the occurrence of erosive processes related to long-lasting subaerial exposure of the continental shelf (surfaces SA, SB and S1 to S5, Figs 3 and 4). Sets I and II were thus interpreted as a succession of depositional sequences induced by repeated glacioeustatic cycles of alternating sea-level lowering and rising. In this context, the upper and/or lower bounding surfaces of each sequence (surfaces SA, SB and $\mathrm{S} 1$ to S5) were interpreted as master sequence boundaries (sensu HUNT; TUCKER, 1992; PLINT; NUMMEDAL, 2000), since their unconformable expression is the most easily identifiable shelf-wide surface on the seismic lines. Each surface represents a diachronous horizon originated at times of maximum sea-level lowstands and most extensive subaerial exposure of the continental shelf (Fig. 7c), that was subsequently reworked during sea level rises.

Seismic stratigraphic analysis also evidenced highly variable along-dip depositional styles of sequences that compose Set I and Set II. Set I (SqA$\mathrm{SqC}$ ) is a dominantly sigmoidal set of sequences displaying aggradational and progradational components that record both enhanced regional subsidence and/or longer-term relative sea-level rise and higher rates of sediment supply, conditions that are required for the development and subsequent preservation of aggradational depositional units (e.g. seismic facies $P P$ and $S C$ in Fig. 5) (CATUNEANU, 2002; TRINCARDI; CORREGGIARI, 2000).

Subsidence conditions seem to have changed throughout the basin during the deposition of the sequences that make up Set II. For instance, sequences $\mathrm{Sq} 1-\mathrm{Sq} 4$ are characterized by a seaward downstepping succession of prograding clinoforms located on the outer shelf (e.g. seismic facies $O C$ in Fig. 5); these sequences are apparently detached from any preserved inner shelf sedimentary system and are topped by seaward-dipping erosional surfaces that merge landward and form shelf-wide diachronous horizons (Figs 3 and 4). This configuration implies that the generation of accommodation space was less important than during the build-up of Set I. As a consequence, sequences Sq1-Sq4 stack on top of each other and form a composite seaward-thickening progradational wedge that reaches a maximum thickness of about 180-220 m at the level of the present-day offlap break (Figs 3 and 4). According to this stratigraphic architecture, each depositional 
sequence was interpreted as representing a repetition of transgressive-regressive cycles, being essentially composed of thicker regressive deposits and reduced, or even absent, transgressive and highstand units. These prograding elements are indicative of depositional sequences formed under forcedregression conditions (Fig. 7, sensu POSAMENTIER et al., 1992; POSAMENTIER; MORRIS, 2000), whereas the plane-parallel or seaward gently-dipping reflectors, like those observed in sequence Sq4 (Figs 3 and 4), are clearly not part of progradational wedges and have thus been interpreted as indicative of deposition during phases of sea-level rise, preserved either as transgressive and/or highstand sedimentary systems (TRINCARDI; CORREGGIARI, 2000; RIDENTE; TRINCARDI, 2002; CATTANEO; STEEL, 2003; CATUNEANU, 2006; CATUNEANU, 2009). Nevertheless, preservation of forced-regression deposits within stacks of regressive-prograding units requires a subsidence regime capable of inducing the seaward tilting of the margin by, for example, differential compaction and/or overloading subsidence (POSAMENTIER; MORRIS, 2000). In comparison with the sequences of Set I, sequences Sq1-Sq4 (from Set II) exhibit more limited landward extent and show both a progressive seaward progradation and reduced or absent transgressive and/or highstand deposits; their landward pinch-out gradually shifts landwards (Figs 2, 3 and 4), which suggests the generation of accommodation space during deposition of Set II, regardless of the low subsidence rates expected for the thermally old Santos basin (CHANG et al., 1992; MODICA; BRUSH, 2004). Still in the context of the forced-regressive shelf-edge wedges of sequences of Set II, the high-angle dipping foresets $\left(\sim 0.8-1.0^{\circ}\right)$ that characterize these clinoforms are prone to gravitational instabilities inducive of sediment layer disruption and sediment sliding or slumping (Fig. 3).

Regarding the top seismic sequence Sq5, its stratigraphic architecture supports the interpretation of deposition that occurred under transgressive and highstand conditions. The patchy sedimentary cover that makes up $\mathrm{Sq} 5$ on the outer shelf has been interpreted as transgressive units (in the sense of CATTANEO; STEEL, 2003), deposited by reworking during transgression, and whose preservation has probably been favoured by the occurrence of preexisting erosive depressions imprinted on surface S5 (Figs 2 and $6 \mathrm{c}, \mathrm{d}$ ); these features can be topped by a highly irregular sea-bottom morphology (Fig. 6D), which may correspond to carbonate bioconstructions, already identified in the outer shelf of the study area (SIMỖES, 2007). The dune-like seismic features mapped on the mid-shelf were equally interpreted as having been formed under transgressive conditions, possibly as transgressive lags developed during sealevel stillstands (Figs 2 and 6B); similar sedimentary motifs were observed by RABINEAU et al. (2005) across the continental shelf of the Gulf of Lions, western Mediterranean sea, and have been interpreted as transgressive sedimentary prisms constructed under stillstand conditions. As for the inner shelf laterallycontinuous sedimentary prism, it probably represents sedimentary elements of $\mathrm{Sq} 5$ that developed under sea-level highstand conditions, resulting in a wedgelike feature whose external limit roughly coincides with the $-50 \mathrm{~m}$ isobath (Figs 2 and 6A).

As discussed above, the seismic stratigraphic analysis carried out in this study led to the identification of eight shallow seismic sequences based on their bounding surfaces and on their respective internal architectural elements. However, their age definition based on chronostratigraphic data remains elusive due to the lack of core data. Thus, the only option left was to rely on chronostratigraphic correlations based on the oil industry's exploratory wells that usually neglect the Plio-Quaternary section because of its economic irrelevance for oil. Nonetheless, our chronostratigraphic reconstruction can be partially supported by stratigraphic data from exploratory well P1 (well 1-SPS-0003-SP, located at $110 \mathrm{~m}$ depth) and well P2 (well RJS-001-RJ, located at $49 \mathrm{~m}$ depth, figure $8 \mathrm{a}$ ), which exceptionally offer biostratigraphic dating within the Plio-Quaternary stratigraphic window.

Sediment intervals from well P1 sampled between 245 and $423 \mathrm{~m}$ below the seafloor were dated as Pliocene deposits (undifferentiated Pliocene age, Fig. 8B). Correlation by lateral projection with seismic lines located $2 \mathrm{~km}$ away from well P1 shows that the seismic section extending from sequence $\mathrm{SqA}$ up to the upper portion of sequence $\mathrm{SqB}$ corresponds to the Pliocene interval sampled at well P1 (Fig. 8B). For this reason, sequences $\mathrm{SqA}$ and most of sequence $\mathrm{SqB}$ that compose Set I may be placed within the Pliocene window. Moreover, correlation of GEOMAR seismic lines with chronostratigraphic data from well P2 (Figs $8 \mathrm{c}$, d) also offers additional data for tentative age constraint. By crossing seismic lines of our data base with those of Silva (1992), surface S1 has been correlated with a regional erosive surface, the socalled "Marco P". This horizon lies unconformably over sediments of $\mathrm{SqC}$ that were sampled $150 \mathrm{~m}$ below the seafloor and dated by biostratigraphic proxies (Figs 8c, d). According to SHIMABUKURO (1989, apud SILVA, 1992), sediments recovered at the level of "Marco P" lay at the top of biozone N710 (international biozone NN19 of MARTINI, 1971) indicated by the presence of Pseudoemiliania lacunosa, whose occurrence corresponds to a large time span between 910-440 kyr (early-middle Pleistocene). So, if the dated interval in fact corresponds to the top of biozone N710 (actually subzone D at the top of biozone N710 of ANTUNES, 
1994), surface S1 could then be placed at around 440$500 \mathrm{kyr}$, as stated by SILVA (1992). However, this age would be fully credible only if species younger than $440 \mathrm{kyr}$, like for instance Gephyrocapsa oceanica (ANTUNES, 1994), were found within sediments overlying "Marco P"; unfortunately this is not mentioned by SHIMABUKURO (1989, apud SILVA,
1992). Besides that, in all likelihood, erosive surface "Marco P" shows substantial spatial and temporal variability related to distinct degrees of shelf erosion across the southern Campos and the northern Santos basins.
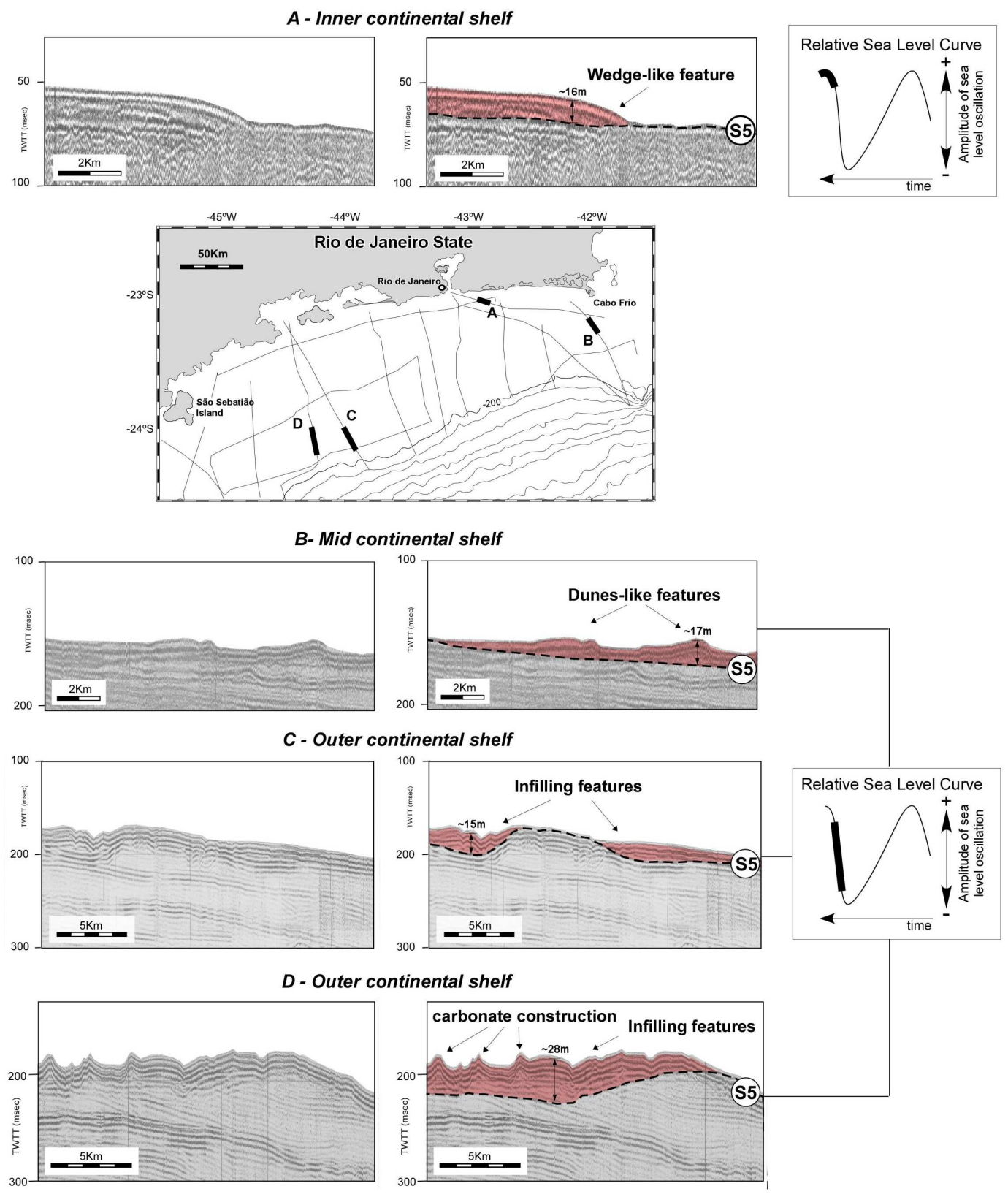

Fig. 6. Zoom-in of single-channel seismic lines to illustrate the varying architectural style of sequence Sq5 across the continental shelf of the study area. 


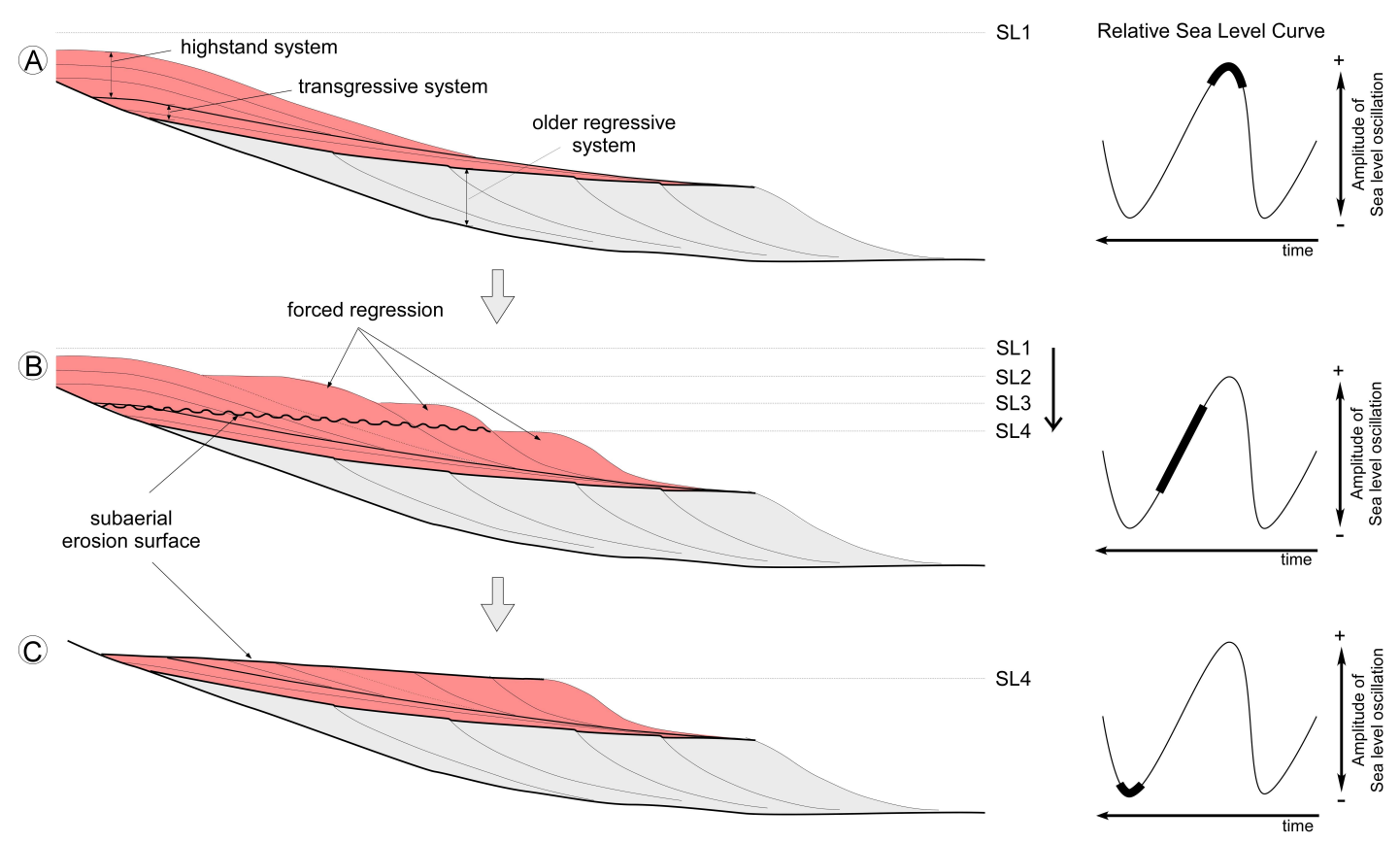

Fig. 7. Simplified conceptual model of regressive sequences based on seismic evidences and depositional geometries observed in the upper set of depositional sequences (Sq1-Sq4) of the sedimentary record of the continental shelf off Rio de Janeiro State. $\mathrm{SL}=$ sealevel (modified from RIDENTE; TRINCARDI, 2002).

Nonetheless, despite the scant amount of available chronostratigraphic data, it was possible: (1) to place the shallow seismic section $(\sim 300 \mathrm{msec})$ depicted by the mapped sequences of Set I (SqA-SqC) and Set II (Sq1-Sq5) within the Pliocene-Quaternary interval; and (2) to estimate a Quaternary age for the exposure surface S1 (lower-middle Pleistocene, between 910-440 kyr) (Fig. 9a). Therefore, even if time intervals involving deposition of all sequences cannot be fully constrained in the study area, the larger part of the seismic sequences that compose Set I (SqA and part of $\mathrm{SqB}$ ) are of Pliocene age, while the upper part of SqC is Quaternary in age (Figs 8A, 9A and 10). On the other hand, concerning the age of surface $\mathrm{S} 1$, seismic stratigraphic analysis has shown that it is overlain by five depositional sequences (sequences Sq1-Sq5, Figs 3 and 4). Considering that since the Middle Pleistocene ( last 800 kyr; SHACKLETON; OPDYKE, 1976), there is a global prevalence of high frequency fourth-order depositional cycles of circa 100-120 kyr, stratigraphic correlations discussed above hint at a time span of circa 440-500 kyr for the deposition of sequences Sq1 through Sq5 (Fig. 9a). Thus, as the four regressive sequences Sq1-Sq4 exhibit similar internal geometry, as well as a similar relation to their bounding surfaces, it is suggested that they record fourth-order depositional cycles for the last 440-500 kyr. The Pliocene-Quaternary limit would then be placed at an undetermined horizon between the upper portion of sequence $\mathrm{SqB}$ and the upper portion of sequence SqC (Figs 9 and 10).

In this scenario, the first four sequences of Set II would encompass the succession of oxygen marine isotope stages (MIS) 12 to 2 (RABINEAU, 2006, Fig. 9B): Sq1 would be the record of deposition between MIS 12 and 10 (ca. 430-450 to 330-350 kyr $\mathrm{BP})$; Sq2 would be correlated to deposition that took place between MIS 10 and 8 (ca. 330-350 to 230-250 kyr BP); Sq3 would be related to MIS 8 and 6 (ca. $230-250$ to $130-140 \mathrm{kyr} \mathrm{BP}$ ); and $\mathrm{Sq} 4$ would be the testimony of deposition from MIS 6 to 2 (ca. 130-140 to $30-20 \mathrm{kyr}$ BP). The fact that MIS 5 is represented by the highest sea-level position (up to $\sim 15-20 \mathrm{~m}$ above current sea-level, figure $9 \mathrm{~b}$ ), and that the low sea-level of the subsequent LGM (135-145 m, MIS 2) was at a higher position than the preceding glacial maximum (150-160 m, MIS 6), can possibly explain why sequence $\mathrm{Sq} 4$ is characterized by preserved transgressive and/or highstand units (Figs 3 and 9b). Last but not least, sequence Sq5 is represented by transgressive lags (dune-like features and infilling deposits developed during the Holocene transgression, Figs 2 and 6B, C, D) and the continuous inner-shelf sedimentary prisms deposited under highstand sealevel conditions (Figs 2 and 6A) being thus interpreted as a sequence still under construction. 

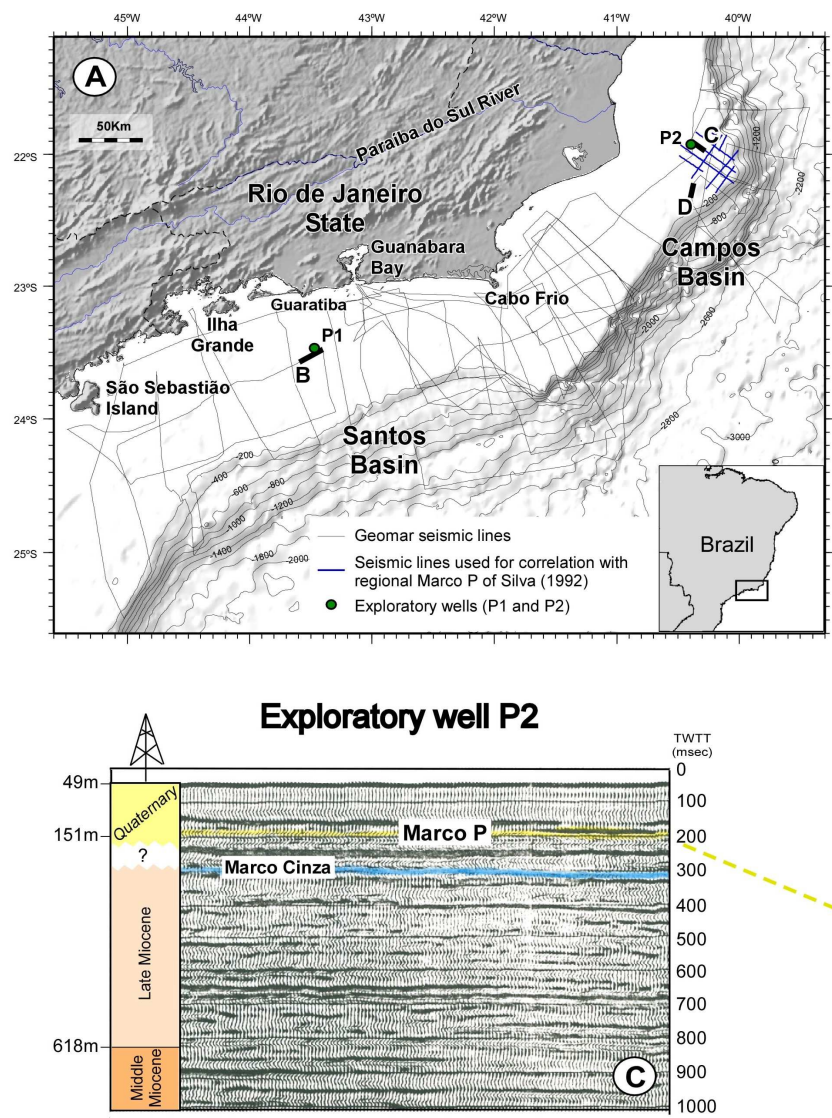

Exploratory well $\mathrm{P} 1$

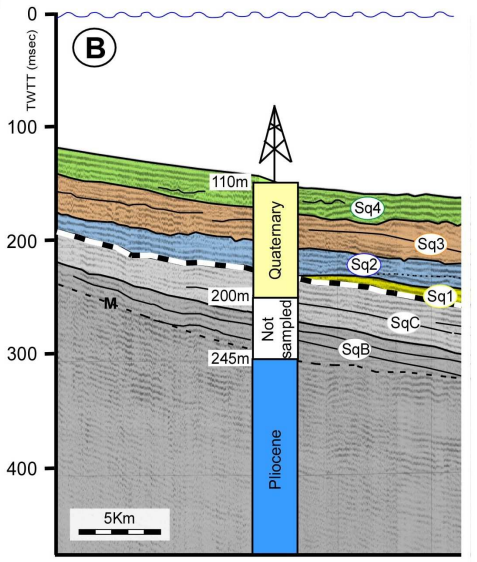

Geomar seismic line

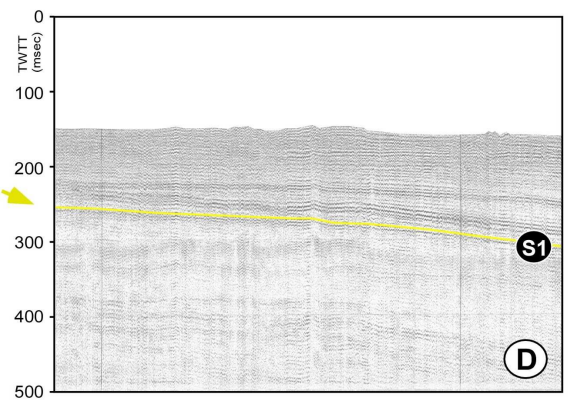

Fig. 8. Well log information of wells P1 and P2 used in this study, as well as their calibration on the respective seismic lines.

A

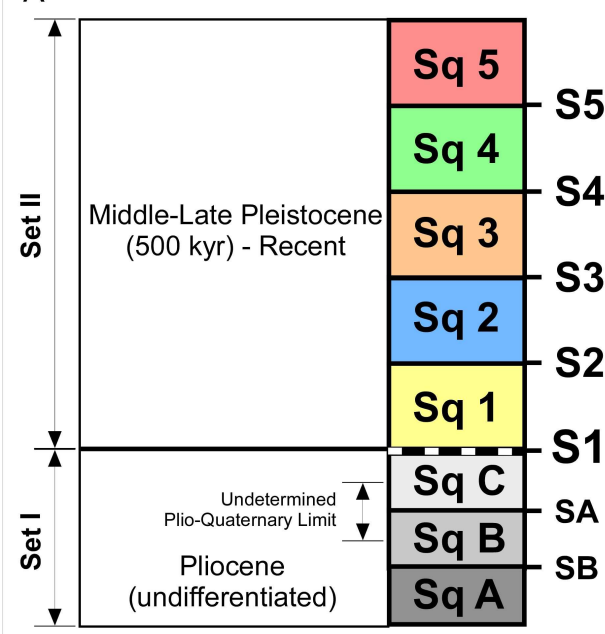

B

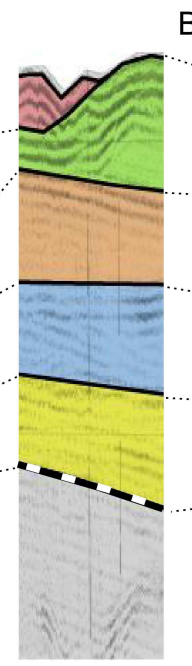

RSL (m) Marine Isotopic

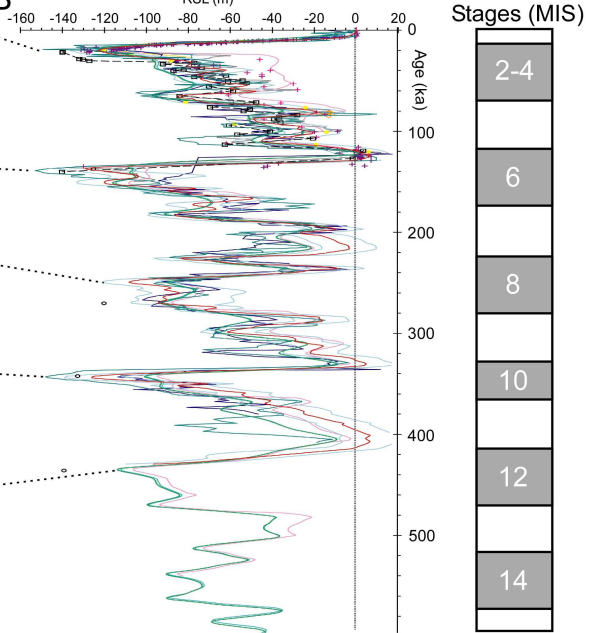

Fig. 9. A- Stratigraphic column showing the correlation of the mapped sequences constrained by chronostratigraphic data from exploratory wells. B- Proposed depositional cyclicity of mapped sequences based on correlation with $\delta^{18} \mathrm{O}$ isotopic "global sealevel curves" compiled by RABINEAU et al. (2006). 


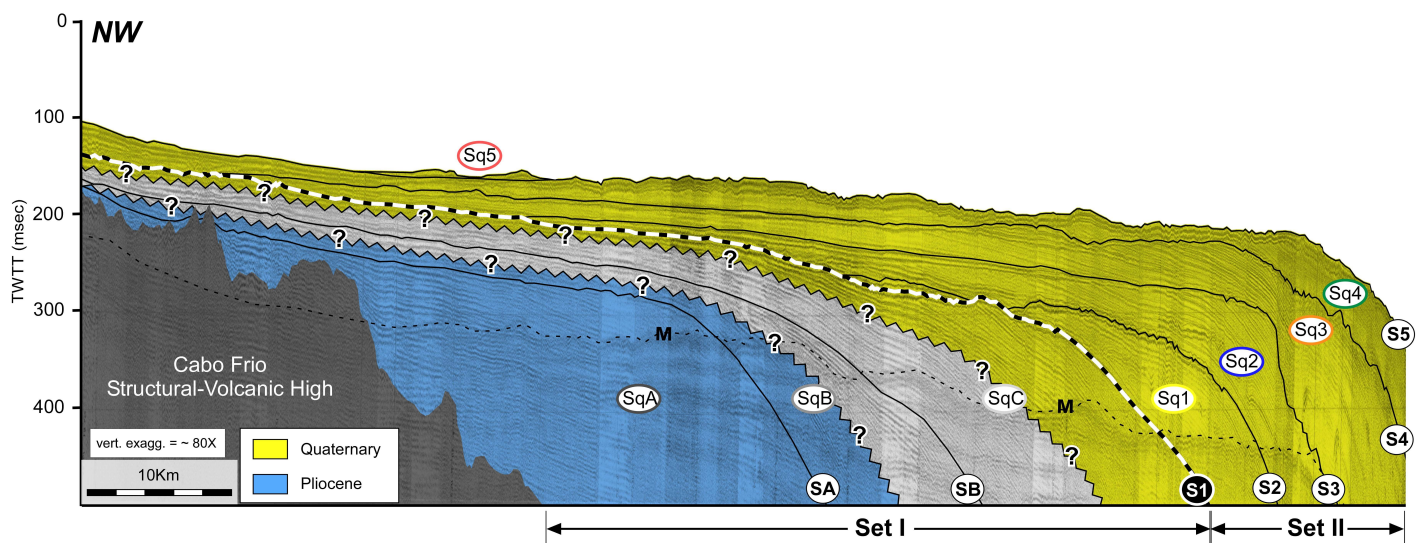

Fig. 10. Interpreted dip single-channel seismic line across the eastern shelf sector off Rio de Janeiro, illustrating ages of the stratigraphic Sets I and II.

The above proposed interpretation of sedimentary architecture of the study area is consistent with many evidences coming from other Quaternary margins worldwide, where the depositional cyclicity is dominated by the falling part of high-frequency, fourth-order glacioeustatic cycles resulting in a sedimentary pattern of stacked forced-regression wedges (e.g. PIPER; AKSU, 1992; SYDOW; ROBERTS, 1994; TRINCARDI; CORREGGIARI, 2000; EVANS et al., 1995; HERNANDEZ-MOLINA et al., 2000; RIDENTE; TRINCARDI, 2002; JIN et al., 2002; LOFI et al., 2003; BERNÉ et al., 2004; OKYAR et al., 2005; RABINEAU et al., 2005; TEZCAN; OKYAR, 2006; GROSSMAN et al., 2006; LIQUETE et al., 2008; TRIPSANAS; PIPER, 2008).

\section{Conclusion}

The seismic analysis of GEOMAR data sets allowed the recognition and mapping of identifiable seismic sequences in the shallow sediment record $(\sim 300 \mathrm{msec})$ of the prograding continental shelf of the northern Santos basin for the first time. Two distinctive sets of stratigraphic sequences, Set I and Set II, were defined and described, constituted by eight mapped seismic sequences $(\mathrm{SqA}, \mathrm{SqB}, \mathrm{SqC}, \mathrm{Sq} 1$ to Sq5) (Figs 3 and 4).

Seismic stratigraphic analysis also evidenced major differences between the depositional styles of Set I and Set II indicating distinctive interplays between base-level variations and sequence preservation. Set I (SqA-SqC) is a dominantly sigmoidal set of sequences that illustrates an aggradational-progradational shelf, reflecting relatively enhanced regional subsidence and/or a longer-term relative sea-level rise, which favoured deposition and preservation of aggrading sedimentary units, as well as the shelf progradation for about $25 \mathrm{~km}$ in the study area (Fig. 4). In contrast, the first four seismic sequences of Set II (Sq1-Sq4) stack on top of each other to form a composite regressive wedge developed under dominant forced-regression conditions; stacked regressive seismic sequences still imply a prevailing subsidence regime, able to induce the seaward tilting of the margin, but also decreasing accommodation space when compared to conditions that seem to have prevailed during the deposition of Set I; under these circumstances, the shelf prograded between circa $15-25 \mathrm{~km}$ in the northern Santos basin (Fig. 3).

Correlation among seismic interpretation, chronostratigraphic data from boreholes (wells P1 and P2, Fig. 8) and isotopic sea level curves (Fig. 9B) supports the hypothesis that sequences Sq1-Sq4 record 100-120 kyr glacioeustatic cycles for the last 440-500 kyr, whereas most sequences of Set I (SqA and part of $\mathrm{SqB}$ ) are Pliocene in age (Fig. 9a). Sequence Sq5 is related to Holocene deposits found in the inner (internal prism) and mid-shelf (transgressive lag deposits) that are hence part of a sequence still under development (Figs 2, 3, 4, 6 and 9).

\section{ACKNOWLEDGEMENTS}

This study was funded by the Brazilian National Research Agency-CNPq (grant 477.458/2006-8) and the Research Agency of Rio de Janeiro State-FAPERJ (grant E-26/110.812/2008). Exploratory well data were provided by ANPBrazilian National Petroleum Agency. We would also like to thank ANP (program PRH 11-UFF) for granting the first author and $\mathrm{CNPq}$ for equally providing research grants for, respectively, the second, the fourth and the last authors (PIBIC/CNPq). 


\section{REFERENCES}

ANTUNES, V. S. Bioestratigrafia dos nanofósseis quaternários da bacia de Campos. Boletim de Geociências da Petrobras, v. 8, n 2/4, p. 295-313. 1994.

ARTUSI, L.; FIGUEIREDO, A. G. Sismografia rasa da plataforma continental de Cabo Frio - Araruama - RJ. Revista Brasileira de Geofísica, v. 25. n. 1, p. 7-16. 2007.

BERNÉ, S.; RABINEAU, M.; FLORES, J. A.; SIERRO, F. J. The impact of quaternary global changes on strata formation - Exploration of the shelf edge in the northwest mediterranean sea. Oceanography, v. 17, n. 4, p. 92-103. 2004.

CATTANEO, A.; STEEL, R. J. T. Transgressive deposits: a review of their variability. Earth Science Reviews, v. 62, p. 187-228. 2003.

CATUNEANU, O. Sequence stratigraphy of clastic systems: concepts, merits, and pitfalls. Geological Society of Africa Presidential Review No. 1. Journal of African Earth Sciences, v. 35, p.1-43. 2002.

CATUNEANU, O. Principles of Sequence Stratigraphy, New York: Elsevier, 2006. 386 p.

CATUNEANU, O; ABREU, V.; BHATTACHARYA, J. P.; BLUM, M. D.; DALRYMPLE, R. W.; ERIKSSON. P. G.; FIELDING, C. R.; FISHER, W. E.; GALLOWAY, W. E.; GIBLING, M. R.; GILES, K. A.; HOLBROOK, J. M.; JORDAN, R.; KENDALL, C. G. St. C.; MACURDA, B.; MARTINSEN, O. J.; MIALL, A. D.; NEAL, J. E.; NUMMEDAL, D.; POMAR, L.; POSAMENTIER, H. W.; PRATT, B. R.; SARG, J. F.; SHANLEY, K. W.; STEEL, R. J., STRASSER, A.; TUCKER, M. E.; WINKER, C. Towards the standardization of sequence stratigraphy. Earth-Science Reviews. Earth Science Reviews, v. 92, p. 1-33. 2009.

CHANG, H. K.; KOWSMANN, R. O.; FIGUEIREDO, A. M. F.; BENDER, A. Tectonics and Stratigraphy of the East Brazil Rift System: an Overview: Tectonophysics, v. 213, p. 97-138. 1992.

CHAPPEL, J.; SHACKLETON, N. J. Oxygen isotopes and sea level. Nature, v. 324, n. 6093, p. 137-140. 1986.

CLARK, P.U.; ARCHER, D.; POLLAN, D.; BLUM J. D.; JOSE, A.; BROVKIN, V.; MIX A.C.; PISIAS N.G.; MARTIN, R. The middle Pleistocene transition: characteristics, mechanisms, and implications for longterm changes in atmospheric pCO2. Quaternary Science Reviews, v. 25, p. 3150-3184. 2006.

COSTA MAIA, R. M. Arcabouço Estratigráfico e Ciclicidade Deposicional dos Sistemas Plataformais ao Largo do Estado do Rio de Janeiro - Bacia de Santos. 2009. 127p. Dissertação (mestrado) Universidade Federal Fluminense, UFF, Niterói.

EVANS, C. D. R; BRETT, C. P.; JAMES, J. W. C.; HOLMES, R. Shallow seismic reflection profiles from the waters of east and southeast Asia - an interpretation manual and atlas. British Geological Survey Technical Report. WC 94/60. 1995.

FLEMING, F. P.; MAIA, R. M. C.; REIS, A. T.; ALVES, E. C.; GORINI, C.; SILVA, C. G.; GUERRA, J. V. Variability and evolution of shallow continental shelf systems off Rio de Janeiro State, Santos Basin - Brazil. Journal of Coastal Research, v. 1, Special Issue 56, p. 617-621, 2009.
FOYLE, A. M.; OERTE, G. F. Transgressive systems tract development and incised-valley fills within a quaternary estuary-shelf system: Virginia inner shelf, USA. Marine Geology, v. 137, p. 227-249. 1997.

GROSSMAN, E. E.; EITTREIM, S. L.; FIELD, M. E.; WONG, F. L. Shallow stratigraphy and sedimentation history during high-frequency sea-level changes on the central California shelf. Continental Shelf Research, v. 26, n.10, p. 1217-1239. 2006.

HERNANDEZ-MOLINA, F. J.; SOMOZA, L.; LOBO, F. Seismic stratigraphy of the gulf of cadiz continental shelf: a model for late quaternary high resolution seismic stratigraphy. In: HUNT, D.; GAWTHORPE, R. (eds). Sedimentary responses to forced regressions. Geological Society, London, Special Publications, v. 172, p. 329-262. 2000.

HUNT, D.; TUCKER, M. E. Stranded parasequences and the forced regressive wedge systems tract: deposition during base-level fall. Sedimentary Geology, v. 81, p. 1-9. 1992.

JIN, J. H.; CHOUG, S. K.; RYANG, W. H. Sequence aggradation and systems tracts partitioning in the mideastern Yellow sea: roles of glacioeustasy, subsidence and tidal dynamics. Marine Geology, v. 184, p. 249271. 2002.

KOWSMANN, R. O.; COSTA, M. O. A. Sedimentação quaternária da margem continental brasileira e das áreas oceânicas adjacentes. REMAC PROJECT (Final Report). Petrobras, Rio de Janeiro, p. 1-55. 1979.

LIQUETE, C.; CANALS, M.; DE MOL, B.; DE BATIST, M.; TRINCARDI, F. Quaternary stratal architecture of the Barcelona prodeltaic continental shelf (NW Mediterranean). Marine Geology, v. 250, n. 3-4, p. 234250. 2008.

LOFI, J.; RABINEAU, M.; GORINI, C.; BERNÉ, S.; CLAUSON, G.; CLARENS, P.; REIS, A. T.; MAUNTAIN, G. S.; RYAN, W. B. F.; STECKLER, M. S.; FOUCHET, C. Plio-quaternary prograding clinoform wedges of the western gulf of lions continental margin (NW Mediterranean) after the messinian salinity crisis. Marine Geology, v. 198, n. 3-4, p. 289-317. 2003.

MAHIQUES, M.; FUKUMOTO, M. M.; SILVEIRA, I. C. A.; FIGUEIRA, R. C. L.; BÍCEGO, M. C.; LOURENÇO, R. A.; MELLO-E-SOUSA, S. H. Sedimentary changes on the Southeastern Brazilian upper slope during the last 35,000 years Anais da Academia Brasileira de Ciências, v. 79, n. 1, p. 171181. 2007.

MAIA, M.; MARTIN, L.; FLEXOR, J. M.; AZEVEDO, A. E. G. Evolução holocênica da planície costeira de Jacarepaguá (RJ). In: XXXII CONGRESSO BRASILEIRO DE GEOLOGIA. Rio de Janeiro, 1984. Proceedings ...... Rio de Janeiro, v. 1, p.105-118, 1984.

MARTIN, L.; DOMINGUEZ, J. M. L.; BITTENCOURT, A. C. S. P. Fluctuating Holocene sea levels in eastern and southeastern Brazil: evidence from multiple fossil and geometric indicators. Journal of Coastal Research, v. 19, p. 101-124. 2003.

MARTINI, E. Standard Tertiary and Quaternary calcareous nanoplankton zonation. In: FARINACI, A. (ed). Conference of planktonic microfossils. Roma, 1970. Proceedings.... Edizioni Tecnoscienza, v. 2, p. 739-785. 1971. 
MITCHUM Jr., R. M.; VAIL, P. R.; SANGREE, J. B. Seismic stratigraphy and global changes of sea level, part 6: Seismic stratigraphy interpretation of seismic reflection patterns in depositional sequence. In: PAYTON, C. E. (ed.). Seismic stratigraphy applications to hydrocarbon exploration, AAPG Memoir 26. Edwards Brothers Inc. Ann Arbor, Michigan. p. 117. 133. 1977.

MODICA, C. J.; BRUSH, E. R. Postrift sequence stratigraphy, paleogeography, and fill history of the deep-water Santos Basin, offshore southeast Brazil. AAPG Bulletin, v. 88, n. 7, p. 923-945. 2004.

MOREIRA, J. L. P.; CARMINATTI, M. Sistemas deposicionais de talude e bacia no Eoceno da Bacia de Santos. Boletim de Geociências da Petrobrás, Rio de Janeiro, v. 12, n. 1, p. 73-87. 2004.

MUEHE, D. Distribuição e caracterização dos sedimentos arenosos da plataforma continental interna entre Niterói e Ponta Negra. Revista Brasileira de Geociências, v. 19, n. 1, p. 25-36. 1989.

MUEHE, D.; CARVALHO, V. G. Geomorfologia, cobertura sedimentar e transporte de sedimentos entre a Ponta de Saquarema e o Cabo Frio (RJ). Boletim do Instituto Oceanográfico, USP, v. 41, n. 1/2, p. 1-12. 1993.

MUEHE, D.; VALENTINI, E. O Litoral do Rio de Janeiro: uma caracterização físico-química. FEMAR, Rio de Janeiro, 1998. $123 \mathrm{p}$

OKYAR, M.; ERGIN, M.; EVANS, G. Seismic stratigraphy of Late Quaternary sediments of western Mersin Bay shelf, (NE Mediterranean Sea). Marine Geology, v. 220 p. 1-4, p. 113-130. 2005.

PIPER, D. J. W.; AKSU, A. E. Architecture of stacked Quaternary deltas correlated with global oxygen isotopic curve. Geology, v. 20, p. 415-418. 1992.

PLINT, A. G.; NUMMEDAL, D. The falling stage systems tract: recognition and importance in sequence stratigraphy. In: HUNT, D.; GAWTHORPE, R. (eds). Sedimentary responses to forced regressions. Geological Society, London, Special Publications, v. 172 , p. 1-17. 2000

POSAMENTIER, H. W.; ALLEN, P. G.; JAMES, D. P. TESSON, M. Forced regression in a seismic stratigraphic framework: concepts, examples and exploration. AAPG Bulletins, v. 76, p. 1687-1709. 1992.

POSAMENTIER, H. W.; MORRIS, W. R. Aspects of the stratal architecture of forced regressive deposits. In: HUNT, D.; GAWTHORPE, R. L. (eds). Sedimentary responses to forced regressions. Geological Society, London, Special Publications, v. 172, p.19-46. 2000.

RABINEAU, M.; BERNÉ, S.; ASLANIAN, D.; OLIVET, J. L.; JOSEPH, P.; GUILLOCHEAU, F.; BOURRILLET, J. F.; LEDREZEN, E.; GRANJEAN, D. Sedimentary sequences in the Gulf of Lions: a record of 100,000 years climatic change. Marine and Petroleum Geology, v. 22, n. 6-7, p. 775-804. 2005 .

RABINEAU, M.; BERNÉ, S.; OLIVET, J. L.; ASLANIAN, D.; JOSEPH, P. Paleo sea levels reconsidered from direct observation of paleoshoreline position during Glacial Maxima (for the last 500,000 yr). Earth and Planetary Science Letters, v. 252, p. 119-137. 2006.

RIDENTE, D.; TRINCARDI, F. Eustatic and tectonic contro of deposition and lateral variability of quaternary regressive sequences in the Adriatic basin (Italy). Marine geology, v. 184, p. 273-293. 2002.
SHACKLETON, N. J.; OPDYKEO, N. D. Oxygen-isotope and paleomagnetic stratigraphy of Pacific core V28-239: Late Pliocene to latest Pleistocene. Geological Society of America, v. 145, p. 449-464. 1976.

SILVA, A. Evolução sedimentar pós-miocênica na área nordeste da Bacia de Campos, Rio de Janeiro. 1992. 57p. Dissertação (Mestrado) - Universidade Federal do Rio de Janeiro, UFRJ, Rio de Janeiro.

SIMÕES, I. C. V. P. Aplicação da batimetria multifeixe para definição da morfologia detalhada do fundo marinho ao largo da laguna de Araruama e Arraial do Cabo - RJ. 2007. 121p. Dissertação (Mestrado) Universidade Federal Fluminense, UFF, Niterói.

SMITH, W. H. F; SANDWELL D. T. Global Seafloor topography from satellite altimetry and ship depth soundings. Science, V. 227, P. 1956-1962. 1997.

SYDOW, J.; ROBERTS, H. H. Stratigraphic framework of a late Pleistocene shelf-edge delta, northeast Gulf of Mexico. AAPG Bulletin, v. 78, p. 1276-1312. 1994.

TESSON, M.; RAVENE, C.; ALLEN, G. P. Applications des concepts de stratigraphie séquentielle à un profiles sismique haute resolution traverse à la plate-forme rhôdanienne. Comptes rendus de l'Academie de sciences de Paris, v. 310, s. II, p. 565-570. 1990.

TESSON, M.; POSAMENTIER, H. W.; GENSOUS, B. Stratigraphic organization of late Pleistocene deposits of the western part of the golf du Lion shelf (Languedoc shelf) western Mediterranea sea, using high-resolution seismic and core data. AAPG Bulletin, v. 84, p. 119150. 2000.

TEZCAN, D.; OKYAR, M. Seismic stratigraphy of Late Quaternary deposits on the continental shelf of Antalya Bay, Northeastern Mediterranean. Continental Shelf Research, v. 26, n. 14, p. 1595-1616. 2006.

TRINCARDI, F.; CORREGGIARI, A. Quaternary forcedregression deposits in the Adriatic basin and the record of composite sea-level cycles. In: Seismic response to forced regression. In: HUNT, D.; GAWTHORPE, R. L. (eds). Sedimentary responses to forced regressions. Geological Society, London, Special Publications, v. 172, p. 245-269. 2000.

TRIPSANAS, E. K.; PIPER, D. J. W. Late Quaternary stratigraphy and sedimentology of Orphan Basin: Implications for meltwater dispersal in the southern Labrador Sea. Palaeogeography, Palaeoclimatology, Palaeoecology, v, 260, n. 3-4, p. 521-539. 2008.

TURCQ, B.; MARTIN, L.; FLEXOR, J. M.; SUGUIO, K.; PIERRE, C.; TASAYACO-ORTEGA, L. Origin and Evolution of the Quaternary Coastal Plain between Guaratiba and Cabo Frio, State of Rio de Janeiro, Brazil. In: KNOPPERS, B.; BIDONE, E. D.; ABRÃO, J. J. (Eds). Environmental Geochemistry of Coastal Lagoon Systems, Série Geoquímica Ambiental, Rio de Janeiro, Brazil, v. 6, p. 25-46. 1999.

(Manuscript received 06 July 2009; revised 27 November 2009; accepted 09 March 2010) 